\title{
Coptic Texts from a Private Collection in Sweden
}

In spring of this year, I had the opportunity to examine three objects in a private collection in Sweden. The present owners acquired them in the middle of the last century, but have no further details about the objects. Since they do not belong to a public collection, the objects are referred to below as PC-SE for Private Collection in Sweden. The three objects are two ostraca and a wooden piece inscribed on both sides. While one of the ostraca is from an $18^{\text {th }}$ dynasty Deir el-Bahari context and will hence be included in Malte Römer's forthcoming edition of these texts $\left({ }^{1}\right)$, the two other, i.e. the remaining ostracon and the wooden piece, bear Coptic texts. The ostracon is a Theban tax receipt issued by the scribe Psate son of Pisrael. The text on the wooden board seems to be a school exercise, whose content is difficult to identify due to its bad state of preservation.

\section{Tax receipt for diagraphon}

The tax receipt records the payment of 1 solidus for the first instalment of the taxes of the indiction year 7 for the poll-tax (diagraphon) of a deacon called Elias.

O. PC-SE Inv. 2

$13 \times 7,2 \times 1 \mathrm{~cm}$

Thebes (Djeme)

FIG. 1

24.6.724

The ostracon is complete except for a chip to the top-right corner and some surface chips, neither of which leads to loss of the text. The back of the document is blank. Even though unsigned the tax receipt can be attributed to the scribe Psate son of Pisrael, who wrote the largest number of such tax receipts

(*) I would like to express my gratitude to the present keepers of the objects for allowing me to publish them. Furthermore, I owe gratitude to Heike Behlmer (Göttingen), Anne Boud'hors (Paris), Jenny Cromwell (Copenhagen), and Sami Uljas (Uppsala) for their help in various ways as well as the editors and reviewers of the Chronique.

(1) In preparation, see for the time being his preliminary report, M. RÖMER, "Miszellen zu den Ostraka der 18. Dynastie aus Deir el-Bahri und dem Asasif”, The Workman's Progress. Studies in the Village of Deir el-Medina and other Documents from Western Thebes in Honour of Rob Demarée (Leiden, 2014), pp. 211-218.

Chronique d'Égypte XCI (2016), fasc. 182 - doi: 10.1484/J.CDE.5.113219 
from Djeme and who was active between 713/14-724/25. $\left(^{2}\right)$ Some of distinctive features of his writing can be observed here: he writes eIcC instead of EIC and uses the plural apıөmid instead the singular apıөmion. Accordingly our date, i.e., a Paoni $30^{\text {th }}$ of a $8^{\text {th }}$ indiction can be calculated as June $24^{\text {th }} 724$ then. A financial administrator (apê) named Peter (Petros) $\left(^{3}\right.$ ) certified the present receipt. Quite interestingly O. Hamb.Copt.Inv. VI was written on the very same day by Psate but certified by another financial administrator, the apê Êlias. $\left(^{4}\right)$

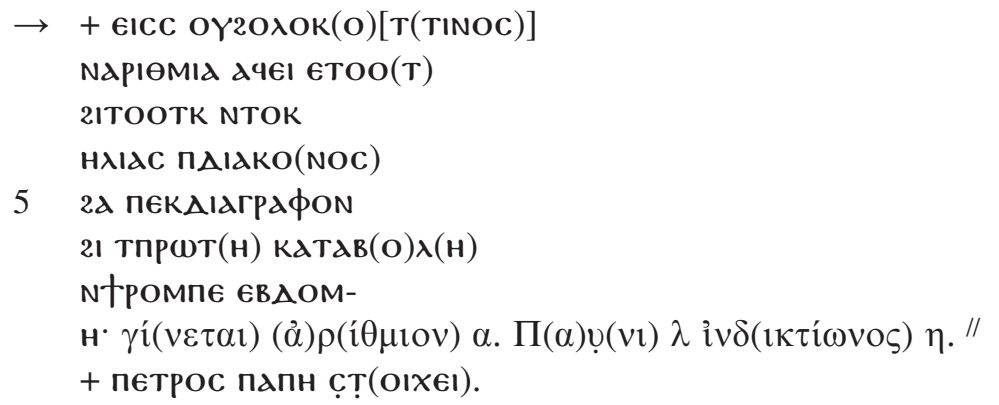

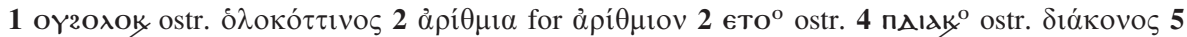

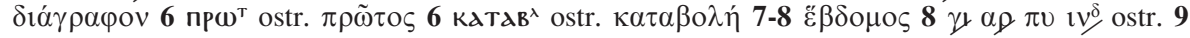
$\sigma \tau \mathrm{ol} \chi \varepsilon \tilde{\mathrm{i} v}$

$"+$ Here is one reckoned solidus, it came to me from you, Elias, the deacon, for your poll-tax in the first instalment of this seventh year. That is: 1 reckoned (solidus). Paoni $30^{\text {th }}, 8^{\text {th }}$ indiction. + Peter the apê agrees".

1 The form of the $Y$ has a slightly unusual flattened form, without a vertical stem, but similar forms of $\gamma$ are found in O.Hamb.Copt. Inv. VI, 1 (DelatTRE \& VANTHIEGHEM, "Sept reçus" [n. 4], p. 92).

2 The scribe more or less squeezed the eтоo into the end of the line and wrote the second $\mathrm{o}$ supra lineam. The final $\mathrm{T}$ seems to have been omitted unless it was written above the second $\mathrm{o}$ in the lacuna.

5 A deacon called Elias is known as the scribe of O.Crum 175, an acknowledgement of debt from the Theban region. It is not clear whether the two attestations refer to the same individual.

(2) A. Delattre \& J.-L. Fournet, "Le dossier des reçus de taxe thébains et la fiscalité en Égypte au début du VIIIe siècle", Coptica Argentoratensia. Textes et documents de la troisième université d'été de papyrologie copte (Strasbourg, 18-25 juillet 2010) (P. Stras. Copt.) (Paris, 2014), pp. 209-245, in part. pp. 231-234.

(3) See W. Till, Prosopographie, p. 174, to which now O.Ashm.Copt. 4, SB Kopt. II 1012 \& 1013 should be added.

(4) A. Delattre \& N. Vanthieghem, «Sept reçus de taxe thébains du viII ${ }^{\mathrm{e}}$ siècle», JCoptS 16 (2014), pp. 89-102, in part. pp. 91-92. 


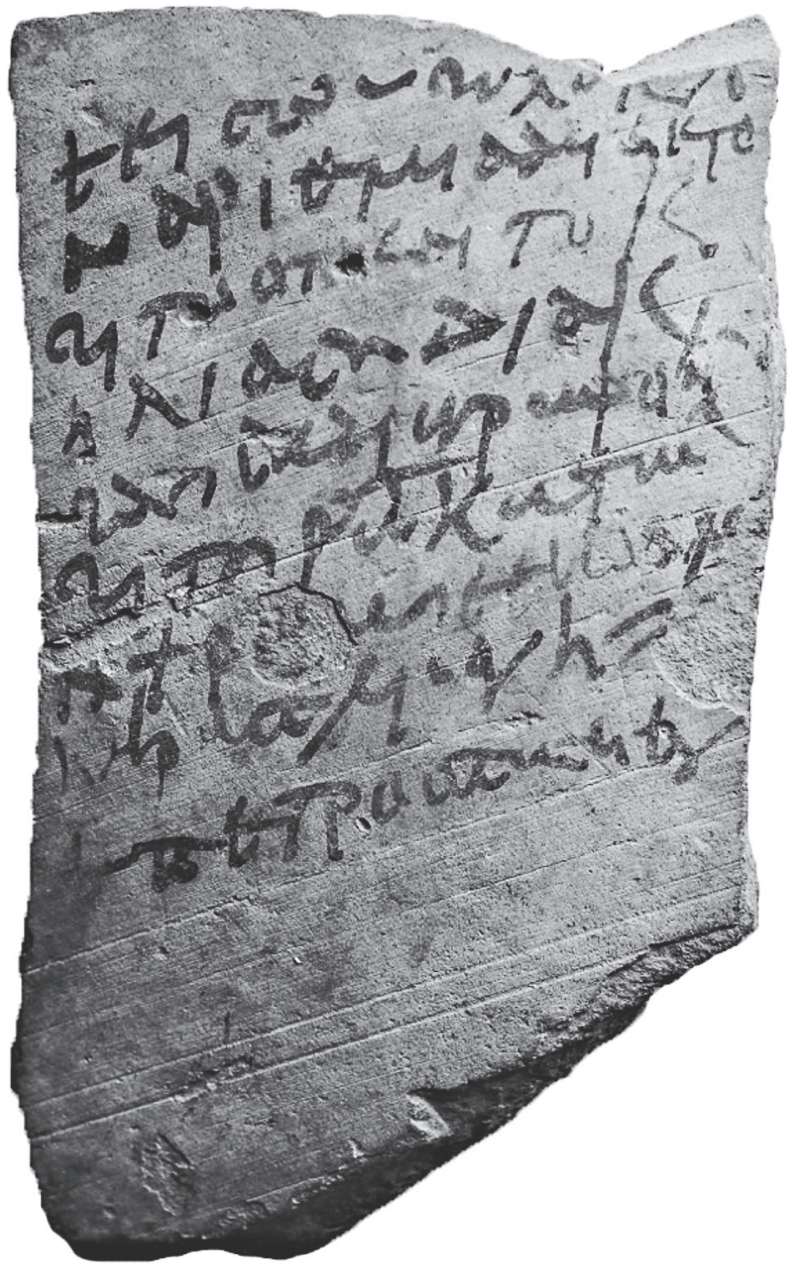

FIG. 1 - O. PC-SE Inv. 2

8 The scribe wrote the abbreviation for the month name above the visible $\pi$ into the part of the ostracon where the surface is damaged. The same abbreviation can be found on O.Hamb.Copt. Inv. VI, 8 for Paoni, a text that can be attributed to Psate son of Pisrael as well (see Delattre \& Vanthieghem, "Sept reçus" [n. 4], p. 91-92).

9 The apê Peter is known by other tax receipts dated from the $13^{\text {th }}$ to the $8^{\text {th }}$ indiction, i.e., from $714 / 15$ to $724 / 25$. He added his subscription to texts written by various scribes such as Anastasios (O.Medin.Habu Copt. 220, SB Kopt. II 1012), John son of Lazaros (O.Medin.Habu Copt. 275), Psan son of Basilios (O.Medin.Habu Copt. 338, 1013), and Psate son of Pisrael (O.Medin.Habu Copt. 373, O.Vind.Copt. 74). On a certain amount of texts, however, the scribe is not mentioned such as $O . M e$ din.Habu Copt. 318-322 or O.Vind.Copt. 78. 


\section{Wooden Board}
T. PC-SE Inv. 3
$4,3 \times 14,2 \times 0,7 \mathrm{~cm}$
Unknown provenance
$6^{\text {th }}-8^{\text {th }}$ cent.
FIGG. 2-3

The wooden piece is broken on all sides with no apparent original edges. On what is taken here to be the back, a larger space of the lower part is left blank. The surface is partly rubbed off and the ink smeared or lost. The backside shows water stains. The wood received a white paint coating before the text was written onto the surface in black ink. Due to the state of preservation, the text itself does not help to elucidate what was front and back (or whether both sides actually do belong together).

A list of wooden boards bearing Coptic texts has been compiled by Brashear and Hoogendijk $\left({ }^{5}\right)$ up to the year 1990 , which has been updated by Worp $\left({ }^{6}\right)$ and to which one may add SB Kopt. III 1690 and SB Kopt. IV 1848, as well as some recently published boards in Italian and Norwegian collections. $\left({ }^{7}\right)$ Wooden boards were used for a wide range of text types, as the list illustrates, so the choice of writing material does not help in identifying the text in this instance. However, the script is of a rather upward bilinear type, which might point to a literary text in the wider sense.

\begin{tabular}{|c|c|}
\hline & ]ṂM. . [ \\
\hline & ] E2OYN ENET(G)HQ) [ \\
\hline & 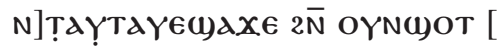 \\
\hline & ] мM[O] \\
\hline 5 & 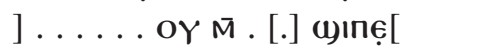 \\
\hline & 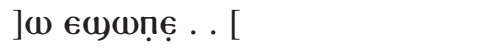 \\
\hline & ]$Y C \cdot N A G \omega 21$ nNOYT $[E$ \\
\hline
\end{tabular}

"... into those spread ones ... in hardship they recited/uttered words ... us not to hasten to $\sin . .$. (verso) .... If ... will remain on God..."

(5) W. Brashear \& F.A.J. HoogendiJK, "Corpus Tabularum Lingearum Ceterarumque Aegyptiarum. Einleitung: Holzbretter als Schriftträger in Ägypten”, Enchoria 17 (1990), pp. 21-54, in part. see p. 44 for the Coptic ones. For T. Heidelberg Inv. 1897 and T. Leiden Inv. 156, 157a and 157b of their list see now A. Delattre \& K.A. Worp, "Trois tablettes de bois du Musée de Leyde”, CdÉ 87 (2012), pp. 361-382 and for T.Vat.Copt. Inv. 112 see now SBKopt. III 1415.

(6) K. Worp, A New Survey of the Greek, Coptic, Demotic and Latin Tabulae Preserved from Classical Antiquity. Version 1.0, Trismegistos Online Publications 6 (Leiden \& Leuven 2012), pp. 55-61.

(7) A. Delattre, H. Harrauer \& R. Pintaudi, "Neues aus der Schule", APapyrol 15 (2015), pp. 29-43, in part. pp. 29-31 \& 34-43 and A. Delattre, "Une tablette de bois de la Bibiothèque Laurentienne (PL III/954)", APapyrol 15 (2015), pp. 45-48. 


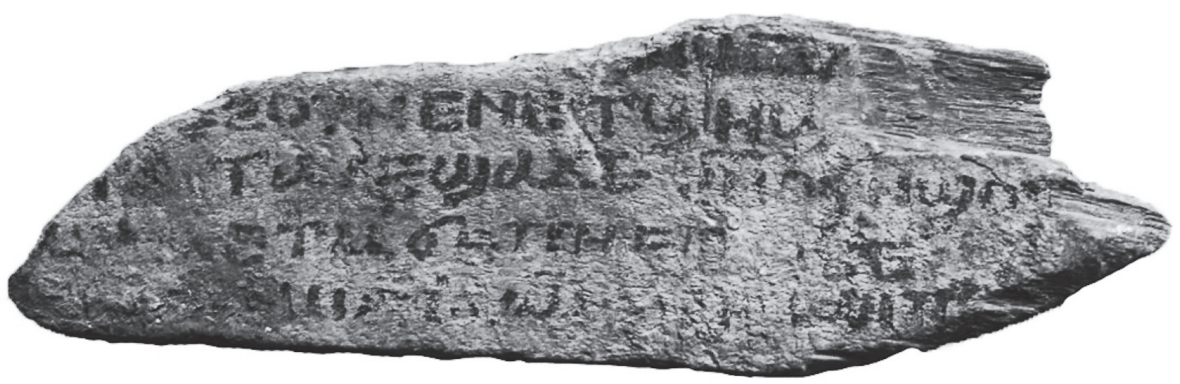

FIG. 2 - T. PC-SE Inv. 3 recto

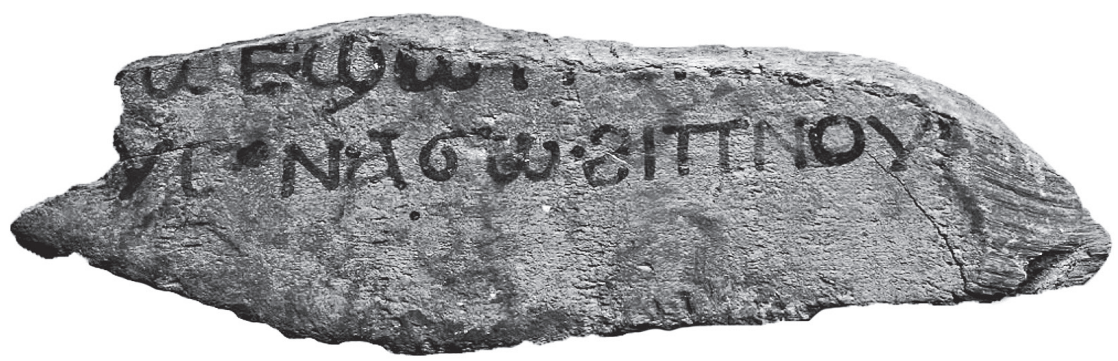

FIG. 3 - T. PC-SE Inv. 3 verso

1 The ink is partly smeared and rubbed off. Of the remaining traces, nothing can be read.

2 As the text breaks off after the $\boldsymbol{\omega}$ ), several verbs are possible here: beside the chosen

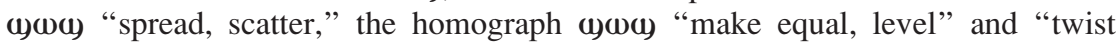
(rope)" is also possible. The fragmentary state of preservation makes it impossible to argue with any certainty for any of these.

3 Both the $T$ and the $d$ at the preserved beginning of the line seem certain. The $Y$ is less so and is surmised only on the ground that the space is sufficient for a narrow letter only. The other option might be to restore the letter 1 and assume a first person singular form, but seeing that the scribe positioned the letters surrounding the 1 in the word $\alpha ı n \in 1.5$ rather close to it, preference to the former is given here. The spatium after $\omega_{d x} \mathbf{x e}$ might be due to the descending stroke of the $\omega$ ) in the line directly above. Although the letter is slightly blurred, the general appearance is more that of an $\mathrm{N}$ than an $\mathrm{M}$. Otherwise, one would have to assume two different ways of writing $\mathrm{M}$ for our scribe, a feature commonly attested not only for Coptic scribes.

4 One would assume an avertive expression "[... admonishes or sim.] us lest we hasten to sin". The sentence (or what remains of it) resembles Old Testament language. There, however, people are said to rush to evil and hasten to bloodshed (cf. Ps 13:4, Pro $1: 16,6: 18$ or Isa 59:7 as well as Rom 3:15 from the New Testament). 
5 No secure traces for the first \pm 5 letters of the line can be discerned. However, the scant traces that are visible make it certain that there was text.

6 Instead of the conditional particle, the group e(y)ne might also stand for preposition plus infinitive, i.e., "to be."

7 The dot appears in an unexpected position, separating the subject from the verb. Therefore, it might have been unintentionally made. The vertical stroke still visible at the end of the line is rather short and hence, in all probability, it is the corner stroke of a $\mathrm{T}$, as is written on the font side. Restoring NOYT or NOYTM is probably ruled out by the (admittedly rather fragmentary) context. 